Research Article

\title{
Anti-Müllerian Hormone Level in Laparoscopic Cystectomy
}

\author{
Kadar Anti Müllerian Hormon pada Laparoskopi Kistektomi \\ Edwin Budipramana, Nusratuddin Abdullah, Telly Tessy \\ Department of Obstetrics and Gynecology \\ Faculty of Medicine Universitas Hasanuddin/ \\ Dr. Wahidin Sudirohusodo Hospital \\ Makassar
}

\begin{abstract}
Objective: To evaluate the impact of laparoscopic cystectomy using cautery and suturing technique on the ovarian reserve represented by the level of Anti-Müllerian Hormone (AMH) serum.

Method: This used prospective cohort study design conducted in Dr. Wahidin Sudirohusodo Hospital, Department of Obstetrics and Gynecology, Faculty of Medicine Universitas Hasanuddin, Makassar, from November 2014 to October 2015. We got total samples of 60 subjects divided into cautery and suturing group. Anti-Mullerian hormone serum test was examined on all subjects pre and post laparoscopic cystectomy.

Result: The result indicated a significant decrease of AMH level undergoing laparoscopic cystectomy both cautery and suturing technique; whereas, more dominant results were showed in the cautery group $(\mathrm{p}<0.05)$. In the $95 \%$ confident interval $(\mathrm{CI})$, the mean decrease of cautery group was $0.87 \mathrm{ng} / \mathrm{ml}$ and $0.31 \mathrm{ng} / \mathrm{ml}$ for suturing group. Both groups showed greater decrease in bilateral cyst, endometriotic type of cyst, and the cyst diameter of less than 5 $\mathrm{cm}$; although these differences were not statictically significant $(\mathrm{p}>0.05)$.

Conclusion: The decline in the number of ovarian reserve as described by the reduction of AMH level occurs significantly in both cauterization and suturing technique, which are more dominant reduction in the cauterization group.

[Indones J Obstet Gynecol 2016; 4-4: 203-207]
\end{abstract}

Keywords: Anti-Müllerian Hormone, laparoscopic cystectomy, ovarian reserve

\begin{abstract}
Abstrak
Tujuan: Mengevaluasi pengaruh laparoskopi kistektomi dengan teknik kauter dan penjahitan terhadap cadangan ovarium yang direpresentasikan oleh kadar serum hormon anti mullerian (AMH).

Metode: Penelitian dengan rancangan kohort prospektif dilaksanakan di RS dr. Wahidin Sudirohusodo, Departemen Obstetri dan Ginekologi Fakultas Kedokteran Universitas Hasanudin (Unhas) di Makassar mulai November 2014 hingga Oktober 2015. Didapatkan sampel sebanyak 60 subjek yang memenuhi kriteria dan dimasukkan pada kelompok kauter dan penjahitan. Semua subjek dilakukan pemeriksaan AMH pre dan post laparoskopi kistektomi.

Hasil: Penelitian menunjukkan penurunan yang bermakna dari kadar AMH pada sampel yang menjalani laparoskopi kistektomi dengan teknik kauter maupun penjahitan, dengan hasil yang lebih dominan pada kelompok kauter $(p<0,05)$. Pada nilai interval kepercayaan (IK) 95\% didapatkan rata-rata penurunan pada kelompok kauter dan penjahitan sebesar 0,87 ng/ml dan 0,31 ng/ml. Pada kedua kelompok didapatkan penurunan AMH yang lebih besar pada kista bilateral, tipe kista endometriosis, dan ukuran kista $<5 \mathrm{~cm}$, namun perbedaan antar kedua kelompok tidak bermakna secara statistik $(p>0,05)$.

Kesimpulan: Penurunan jumlah cadangan ovarium yang digambarkan oleh AMH terjadi secara signifikan pada kedua prosedur hemostasis dengan energi panas kauterisasi dan penjahitan, dengan penurunan lebih dominan pada kelompok kauterisasi.

[Maj Obstet Ginekol Indones 2016; 4-4: 203-207]

Kata kunci: cadangan ovarium, hormon anti-mullerian, laparoskopi kistektomi
\end{abstract}

Correspondence: Edwin Budipramana, edwin_budi_p@yahoo.com

\section{INTRODUCTION}

Ovarian cyst is the most common form of mass on ovarium. The incidence of ovarian cyst was reported between 5 and 15 percent of all the gynecological tumor. ${ }^{1}$

The clinicians usually diagnose ovarian cyst through pelvic examination and ultrasound (USG) imaging modalities; then, they proceed with tumor marker assessment to detect the possibility of malignancy. After diagnosing, they manage the ovarian cyst through either conservative observation or surgery. ${ }^{1}$
Generally, two types of ovarian cyst usually found are functional cyst and endometriosis. Each type of cyst has its own unique characteristics so that the operator can destroy the ovaries differently during performing the laparotomy or laparoscopic cystectomy. In patients with ovarian cyst who undergo laparoscopic cystectomy, there will be normal ovarian tissue damaged during the surgical procedure, either due to sticky tissues or cauterization procedure. Normal ovarian tissue should be maintained as well as possible because it is related to the ovarian ability to maintain the ovulation. $^{2}$ 
Anti-Müllerian Hormone (AMH) is hormone produced by the granulosa cells of primary ovarian follicles. The highest expression is during preantral and antral follicles phase, and it will no longer be detectable when the follicles undergo atresia. AntiMüllerian Hormone serum level is strongly associated with the number of antral follicles, which describe the number of remaining primordial follicles reserve. The reserve of primordial follicles can be used as an illustration of the ovulation induction success. ${ }^{3}$ The more severe of damage to ovarian tissue after cauterization process during laparoscopic cystectomy, the less number of normal follicles left; therefore, AMH level will decline after surgery. ${ }^{4}$ During laparoscopic cystectomy procedure, there is a chance for the damage of normal ovarian tissue because of heat cauterization. As a result of this procedure, the patients have an iatrogenic decline in the number of ovarian follicles causing premature menopause. Apart from that, $\mathrm{AMH}$ is used as a prognostic factor for induction of ovulation in in-vitro fertilization; whereas, it needs sufficient number of ripe ovarian follicles. ${ }^{5}$

Over the last twenty years, AMH, Follicle Stimulating Hormone ( $\mathrm{FSH}$ ), Estradiol ( $\left.\mathrm{E}_{2}\right)$, and inhibin B serum level have been studied to describe the number of ovarian cells reserve. However, FSH, E2, and inhibin $\mathrm{B}$ serum markers are associated with negative feedback on the pituitary-ovarian axis, so that the level of them will be fluctuated during menstrual phase. Meanwhile, the AMH serum level is relatively stable during the cycle. In conclusion, the AMH serum can be used as the reliable marker for ovarian follicle reserve compared with other markers. ${ }^{2}$

This study is conducted on women sufferring from ovarian cyst who had undergone laparoscopic cystectomy with intraoperative cauterization procedure. We compared between the pure suturing and without cauteterization technique. The AMH level serum on each patient was measured before surgery and continued by after surgery. The aim of this study is to determine the significant reduction on the AMH level in both sample groups with different techniques.

\section{METHODS}

This study was held in Dr. Wahidin Sudirohusodo as a teaching hospital with laparoscopic surgery facility, Department of Obstetrics and Gynecology, Faculty of Medicine, Universitas Hasanuddin, Makassar, South Sulawesi. This study used a prospective cohort study design from November 2014 to October 2015. We obtained 60 women suffering from ovarian cyst who had undergone laparoscopic cystectomy procedure.

We examined AMH serum level thorugh blood. The blood samples were taken from each patient at the ventral region of the cubital cavity before and one month after the laparoscopic cystectomy procedure. We analyzed using paired t-test for the AMH serum level to compare the reduction quantity between cauterization and suturing group. We considered statitistically significant if $\mathrm{p}$ value less than 0.05 .

\section{RESULTS}

We collected 60 samples fulfilling the inclusion criteria. They consisted of 30 samples who underwent intraoperative cauterization and the remaining 30 samples performing intraoperative suturing. The characteristics of subjects include age, educational level, marital status, parity, cyst location, type, size, and adhesion (table 1).

Table 1 showed that subjects who had undergone cauterization technique generally were 20-40 years old $(90 \%)$, most of them graduated from senior high school (43\%), had married (83.3\%), and ever delivered more than or equal to 2 times (36\%). The type of cyst was generally endometriosis $(73.3 \%)$, located unilaterally $(73.3 \%)$ with size of $5-10 \mathrm{~cm}(60 \%)$, and the cyst did not show adhesion $(70 \%)$. Meanwhile, subjects doing the suturing techniques were $20-40$ years $(93.3 \%)$, educational level of senior high school (56.7\%), had married (83.3\%) with 1 parity (44\%). Most of cyst typewas endometriosis (63.3\%), located unilaterally $(70.0 \%)$, with size less than $5 \mathrm{~cm}$ (66.7\%), and no adhesion (66.7\%). The statistical result using Shapiro-wilk normality test, we obtained $p$ value more than 0.05 ; therefore, there were no statistically significant differences in age, educational level, marital status, parity, cyst location, type, size, and adhesion between cauterization and suturing group. Thus, both groups described fairly homogenous. 
Table 1. Characteristics of Subjects

\begin{tabular}{|c|c|c|c|c|}
\hline \multirow{2}{*}{ Characteristics } & \multicolumn{2}{|c|}{ Technique } & \multirow[t]{2}{*}{ Total } & \multirow{2}{*}{$\mathbf{p}$} \\
\hline & Cauterization & Suturing & & \\
\hline \multicolumn{5}{|l|}{ Age group (years old) } \\
\hline $20-40$ & $27(90.0)$ & $28(93.3)$ & $55(91.7)$ & \multirow{2}{*}{1.000} \\
\hline$>40$ & $3(10.0)$ & $2(6.7)$ & $5(8.3)$ & \\
\hline \multicolumn{5}{|l|}{ Education } \\
\hline Junior high school & $5(16.7)$ & $5(16.7)$ & $10(16.7)$ & \multirow{3}{*}{0.513} \\
\hline Senior high school & $13(43.3)$ & $17(56.7)$ & $30(50.0)$ & \\
\hline University & $12(40.0)$ & $8(26.7)$ & $20(33.3)$ & \\
\hline \multicolumn{5}{|l|}{ Marital status } \\
\hline Married & $25(83.3)$ & $25(83.3)$ & $50(83.3)$ & \multirow{2}{*}{1.000} \\
\hline Unmarried & $5(16.7)$ & $5(16.7)$ & $10(16.7)$ & \\
\hline \multicolumn{5}{|l|}{ Parity } \\
\hline 0 & $8(32.0)$ & $5(20.0)$ & $13(26.0)$ & \multirow{3}{*}{0.558} \\
\hline 1 & $8(32.0)$ & $11(44.0)$ & $19(38.0)$ & \\
\hline$\geq 2$ & $9(36.0)$ & $9(36.0)$ & $18(36.0)$ & \\
\hline \multicolumn{5}{|l|}{ Cyst location } \\
\hline Unilateral & $22(73.3)$ & $21(70.0)$ & $43(71.7)$ & \multirow{2}{*}{0.774} \\
\hline Bilateral & $8(26.7)$ & $9(30.0)$ & $17(28.3)$ & \\
\hline \multicolumn{5}{|l|}{ Cyst type } \\
\hline Endometriosis & $22(73.3)$ & $19(63.3)$ & $41(68.3)$ & \multirow{2}{*}{0.405} \\
\hline Simple & $8(26.7)$ & $11(36.7)$ & $19(31.7)$ & \\
\hline \multicolumn{5}{|l|}{ Cyst size } \\
\hline$<5 \mathrm{~cm}$ & $12(40.0)$ & $20(66.7)$ & $32(53.3)$ & \multirow{2}{*}{0.195} \\
\hline $5-10 \mathrm{~cm}$ & $18(60.0)$ & $10(33.3)$ & 28 (46.7) & \\
\hline \multicolumn{5}{|l|}{ Adhesion } \\
\hline Present & $9(30.0)$ & $10(33.3)$ & 19 (31.7) & \multirow{2}{*}{1.000} \\
\hline Not present & $21(70.0)$ & $20(66.7)$ & $41(68.3)$ & \\
\hline
\end{tabular}

Table 2. The Difference of AMH Level Pre and Post Surgery According to Surgical Technique

\begin{tabular}{lcccc}
\hline \hline \multirow{2}{*}{ Technique } & \multirow{2}{*}{ Time } & \multicolumn{2}{c}{ AHM Level $(\mathbf{n g} / \mathbf{m l})$} & \multirow{2}{*}{$\mathbf{p}$} \\
\cline { 3 - 4 } & & Mean & SD & \multirow{2}{*}{0.011} \\
\hline Cauterization & Pre surgery & 3.56 & 3.10 & \\
& Post surgery & 2.69 & 2.39 & \multirow{2}{*}{0.028} \\
Suturing & Pre surgery & 4.27 & 2.60 & \\
& Post surgery & 3.90 & 2.55 & \\
\hline \hline
\end{tabular}

In cauterization group, the average AMH level pre surgery was $3.56 \mathrm{ng} / \mathrm{ml}$; whereas, it decreased to $2.69 \mathrm{ng} / \mathrm{ml}$ post surgery. In the suturing group, the average pre surgery AMH level was $4.27 \mathrm{ng} / \mathrm{ml}$; while, the post surgery level was $3.9 \mathrm{ng} / \mathrm{ml}$. Statistical result using paired t-test, we obtained $\mathrm{p}$ value of 0.011 in the cauterization group and 0.028 in the suturing group. It meant that there were statistically significant difference of the AMH level alteration either using cauterization or suturing techniques. 
Table 3. Mean Changes of AMH Level According to Surgery Technique

\begin{tabular}{lccc}
\hline \hline \multirow{2}{*}{ Technique } & \multicolumn{2}{c}{ AMH Level $(\mathbf{n g} / \mathbf{m l})$} & \multirow{2}{*}{$\mathbf{p}$} \\
\cline { 2 - 3 } & Mean & SD & \\
\hline Cauterization & 0.87 & 0.98 & \\
Suturing & 0.31 & 0.28 & 0.005 \\
\hline
\end{tabular}

The average alteration in $\mathrm{AMH}$ level on the cauterization technique was 0.87 ; while, the suturing technique was 0.31 . Statistical result using independent $t$-test showed the $p$ value of 0.005 , it meant that there was significant difference in $\mathrm{AMH}$ level between two groups.

Table 4 explained that in unilateral cyst, the average decline of AMH level in the cauterization technique was $1.14 \mathrm{ng} / \mathrm{ml}$ and $1.00 \mathrm{ng} / \mathrm{ml}$ for suturing technique; whereas, for bilateral cyst, the average decline of AMH level in the cauterization technique was $1.25 \mathrm{ng} / \mathrm{ml}$ and $1.11 \mathrm{ng} / \mathrm{ml}$ in the suturing technique. Based on endometriosis cyst type, the average decline of AMH level in the cauterization technique was $1.23 \mathrm{ng} / \mathrm{ml}$ and 1.05 $\mathrm{ng} / \mathrm{ml}$ in the suturing technique group. On the simple cyst type, the average change of AMH level in both cauterization and suturing techniques was $1.00 \mathrm{ng} / \mathrm{ml}$ each. Based on the presence intraoperative adhesion, the average decline of AMH level in the cauterization and suturing technique was $1.22 \mathrm{ng} / \mathrm{ml}$ and $1.10 \mathrm{ng} / \mathrm{ml}$. Based on the cyst size group $(<5 \mathrm{~cm})$, the AMH level in the cauterization and suturing technique dropped into 1.25 $\mathrm{ng} / \mathrm{ml}$ and $1.00 \mathrm{ng} / \mathrm{ml}$. In the group sized $5-10 \mathrm{~cm}$, the AMH level in the cauterization technique declined $1.11 \mathrm{ng} / \mathrm{ml}$ and $1.10 \mathrm{ng} / \mathrm{ml}$ in suturing technique group. Independent t-test result pointed out $p$ value more than 0.05 on cyst location, type, adhesion, and size. There were not significantly different in the reduction of AMH level between study groups.

\section{DISCUSSION}

This study showed that the average reduction of AMH level was greater in the cauterization group which was statistically significant $(p<0.05)$. We also found that the average AMH serum level dropped more largely on the sample with bilateral cyst (mean $1.25 \mathrm{ng} / \mathrm{ml}$ ), endometriosis cyst (mean $1.23 \mathrm{ng} / \mathrm{ml}$ ), presence of intraoperative adhesion (mean $1.22 \mathrm{ng} / \mathrm{ml}$ ) and cysts sized $<5 \mathrm{~cm}$ (mean $1.25 \mathrm{ng} / \mathrm{ml}$ ); however, they were not statistically significant ( $p>0.05)$. Another study by Celik, et al. also found that decreasing level of AMH was seen in bilateral, endometriosis cysts sized $<5 \mathrm{~cm}$. In small bilateral cyst, it was likely that the number of healthy ovarian tissue damaged or taken away would be a lot through observing the reduction of AMH level. ${ }^{6}$

Intraoperative cauterization procedure uses heat energy to burn tissues during hemostasis process. Heat from cauter can damage the surrounding healthy ovarian tissue and cause more primordial follicles damage. It is illustrated thorugh

Table 4. Difference of Homone Level According to Cyst Location, Adhesion, Size, and Type

\begin{tabular}{lccccc}
\hline \multirow{2}{*}{ Cyst } & \multicolumn{2}{c}{ Cauterization } & \multicolumn{2}{c}{ Suturing } & \multirow{2}{*}{ p } \\
\cline { 2 - 4 } & $\mathbf{n}$ & Mean (SD) & $\mathbf{n}$ & Mean (SD) & \\
\hline Location & 22 & $1.14(0.35)$ & 21 & $1.00(0.00)$ & 0.083 \\
Unilateral & 8 & $1.25(0.46)$ & 9 & $1.11(0.33)$ & 0.485 \\
Bilateral & & & & \\
Type & 22 & $1.23(0.43)$ & 19 & $1.05(0.23)$ & 0.107 \\
Endometriosis & 8 & $1.00(0.00)$ & 11 & $1.00(0.00)$ & - \\
Simple & 9 & $1.22(0.44)$ & 10 & & \\
Adhesion & 21 & $1.14(0.36)$ & 20 & $1.10(0.32)$ & 0.493 \\
Present & & & & & 0.083 \\
Not present & 12 & $1.25(0.45)$ & 20 & $1.00(0.00)$ & \\
Size & 18 & $1.11(0.32)$ & 10 & $1.11(0.32)$ & 0.931 \\
$<5 \mathrm{~cm}$ & & & & \\
$5-10 \mathrm{~cm}$ & & & & & \\
\hline \hline
\end{tabular}


the higher AMH level reduction. ${ }^{7}$ In the suturing group, AMH reduction may occur because the operator accidentally drawed the ovarian parenchym during the excision of cyst wall. According to Roman, it generally happened because there was no clear barrier between cyst wall lining and ovarian cortex histologically. Therefore, it is estimated that the cyst wall excision can cause ovarian reserve reduction. ${ }^{8}$

Most of the ovarian cyst patients in this study were 20-40 years old. This was according to study by Tzadik which they stated that the peak incidence of ovarian cyst was on the reproductive aged women. ${ }^{9}$ In terms of education, the majority of subjects was well educated. It was related to the ovarian cyst characteristic symptoms, namely asymptomatic for functional/simple cyst, or cyclic pain for endometriosis cyst. Patients with sufficient education will have good self-sensibility to feel the disorder and they will immediately check themselves despite of slight complaint.

The most common cyst found in this study was endometriosis cyst. This was in accordance with the highest incidence of endometriosis in reproductive aged women, both married and unmarried, where major symptoms complaint were dysmenorrhea, chronic pelvic pain, and infertility. ${ }^{2}$

Pre surgery AMH level obtained were varied. According to La Marca, AMH level was stable throughout the menstrual cycle compared with other ovarian reserve markers; although the result showed various among individuals. It occured because there was wide variability of the ovarian reserve in each individual. Currently, we still need further study in AMH level according to race, body mass index (BMI), and exposure to cigarette smoke. ${ }^{10}$

\section{CONCLUSION AND RECOMMENDATION}

The decline in the number of ovarian reserve as described by the reduction of AMH level occurs significantly in both cauterization and suturing technique, which are more dominant reduction in the cauterization group. This suggests that $\mathrm{t}$ cauterization using heat energy causes wide range of ovarian tissue damage. Further study should be conducted to evaluate other causes of AntiMüllerian hormone level reduction other than iatrogenic factors, such as surgery.

\section{REFERENCES}

1. Schorge J, Schaffer J, Halvorson L, et al. Pelvic mass: Cystic ovarian masses. Williams Gynecology. Texas: McGraw-Hill; 2008: $210-2$.

2. Hwu YM, Wu SY, Li SH, et al. The impact of endometrioma and laparoscopic cystectomy on serum anti-Müllerian hormone levels. Reprod Biol Endocrinol. 2011; 9: 80.

3. Practice Committee of the American Society to Reproductive Medicine. Testing and interpreting measures of ovarian reserve: A committee opinion. Fertil Steril. 2012; 98(6): 1407-19.

4. Visser JA, de Jong FH, Laven JS, et al. Anti-Müllerian hormone: A new marker for ovarian function. Reprod. 2006; 131(1): e1-9.

5. Raffi F, Metwally M, Amer S. The impact of excision of ovarian endometrioma on ovarian reserve: A systematic review and meta-analysis. J Clin Endocrinol Metab. 2012; 97(9): 3146-54.

6. Celik HG, Dogan E, Okyay E et al. Effect of laparoscopic excision of endometriomas on ovarian reserve: serial changes in the serum antimullerian hormone levels. Fertil Steril. 2012; 97(6): 1472-8.

7. Massarweh NN, Cosgriff N, Slakey DP. Electrosurgery: History, principles, and current and future uses. Am Coll Surg. 2005; 202(3): 520-30.

8. Roman H, Kitajima M, Khan KN, et al. Anti-Müllerian hormone level and endometrioma ablation using plasma energy. JSLS. 2014; 18(3).

9. Tzadik M, Purcell K. Benign disorders of the ovaries dan oviducts. Current diagnosis and treatment: Obstetrics and gynecology $10^{\text {th }}$ ed. USA: McGraw-Hill; 2007: 654-61.

10. LaMarca A, Grisadi V, Griesinger G. How much does AMH really vary in normal women? Int J Endocrinol. 2013; 959487. 